\title{
Uroguanylin and guanylate cyclase $C$ in the human pancreas: expression and mutuality of ligand/receptor localization as indicators of intercellular paracrine signaling pathways
}

\author{
H Kulaksiz and Y Cetin \\ Department of Molecular Cell Biology, Institute of Anatomy and Cell Biology, Philipps University, Marburg, Germany \\ (Requests for offprints should be addressed to Y Cetin, Abt. Molekulare Zellbiologie, Institut für Anatomie und Zellbiologie, Philipps-Universität Marburg, \\ Robert-Koch-Str. 6, D-35033 Marburg, Germany; Email: Cetiny@mailer.uni-marburg.de)
}

\begin{abstract}
The intestinal peptide hormone uroguanylin regulates electrolyte/fluid transport in the gastrointestinal epithelium by binding to its receptor, guanylate cyclase $\mathrm{C}$ (GC-C), and thus specifically coupling to activation of cystic fibrosis transmembrane conductance regulator (CFTR). Since CFTR is crucially involved in pancreatic electrolyte secretion, we investigated the human pancreas for expression and cell-specific localization of uroguanylin and guanylate cyclase $\mathrm{C}$ as potential regulatory components of pancreatic electrolyte secretion. RT-PCR analyses with specific primers revealed that uroguanylin and $\mathrm{GC}-\mathrm{C}$ are expressed in the human pancreas (and in the duodenum, used as positive control); at the translational level, western blotting analyses with peptide- and regionspecific antibodies identified the presence of $12.5 \mathrm{kDa}$ uroguanylin and $130 \mathrm{kDa}$ GC-C in both human pancreatic and intestinal extracts. At the cellular level, uroguanylin and GC-C immunoreactivities were absent from the islets of Langerhans but were exclusively confined to the exocrine parenchyma. Hence, uroguanylin was localized
\end{abstract}

to the centroacinar cells typical of the pancreas, and also to epithelial cells of the intercalated, intralobular and interlobular ducts where the peptide was primarily concentrated adluminally to the apical portion of the respective cells. Coincidently, correlative studies localized the GC-C receptor to the epithelial cells of the ductal network, where it was confined exclusively to the apical cell membrane that evidently represents the functionally relevant target membrane domain for the regulatory peptide. In view of the fact that CFTR is highly expressed in pancreatic ductal cells where uroguanylin and its receptor are also localized, we assume that uroguanylin, an intrinsic pancreatic peptide, is involved in the regulation of electrolyte/water secretion in the ductal system via GC-C and CFTR. The particular cellular expression of uroguanylin in duct cells and the localization of $\mathrm{GC}-\mathrm{C}$ to the duct cell apical membrane domain predict a novel route of intercellular signaling and luminal activation of $\mathrm{GC}-\mathrm{C}$ via the pancreatic juice.

Journal of Endocrinology (2001) 170, 267-275

\section{Introduction}

Uroguanylin is a circulating peptide hormone, originally isolated from intestinal mucosa and urine (Hamra et al. 1993, Miyazato et al. 1996). Since the discovery of guanylin in the intestine (Currie et al. 1992) and of lymphoguanylin in the spleen (Forte et al. 1999), it has become evident that these small peptides belong to a common family of guanylins. Uroguanylin has been localized primarily to endocrine cells such as in enterochromaffin (ECL)-like cells of the stomach (Date et al. 1999), and in somatostatin and enterochromaffin cells of the intestine (Perkins et al. 1997, Magert et al. 1998), guanylin proved to occur mainly in paracrine/luminocrine secretory epithelial cells of the gastrointestinal tract (de Sauvage et al. 1992, Lewis et al. 1993, Cetin et al. 1994, Krause et al. 1997) and of the small airways (Cetin et al. 1995), but also in specific cell types of the hypophysis (D'Este et al. 2000). The function of lymphoguanylin remains to be clarified, but uroguanylin and guanylin proved to act as local regulators of intestinal and renal electrolyte and water transport (Cuthbert et al. 1994, Seidler et al. 1997, Forte et al. 2000). Evidence accumulated that this function is mediated by the guanylate cyclase C (GC-C), which is considered to be the true apical membrane receptor for the endogenous ligands uroguanylin and guanylin (Schulz et al. 1990, Garbers 1992). Stimulation of GC-C by these peptide agonists results in an increase of the intracellular cGMP concentration (Garbers 1992), which mediates activation of the cystic fibrosis $(C F)$ gene product, cystic fibrosis transmembrane conductance regulator (CFTR) (Vaandrager et al. 1998) via the cGMP-dependent protein kinase II (Lohmann et al. 1997) and finally stimulates transepithelial $\mathrm{Cl}^{-}$and $\mathrm{HCO}_{3}{ }^{-}$secretion (Cuthbert et al. 
1994, Seidler et al. 1997, Joo et al. 1998). The pivotal role of CFTR in epithelial ion transport became evident because it was found that mutations in the $C F$ gene severely affect electrolyte secretion in various organs (Quinton 1999). Because the effects of the guanylin peptides on $\mathrm{Cl}^{-}$conductance disappeared in the colon of CF mice, it became clear that the guanylins act as specific regulators of CFTR function (Cuthbert et al. 1994, Seidler et al. 1997, Joo et al. 1998).

As CFTR is highly expressed in the pancreas (Trezise \& Buchwald 1991), where it is clearly involved in the transepithelial ion transport within the ductal system (Case \& Argent 1993, Lee et al. 1999), the question arises whether GC-C, and especially guanylins, also exist in the pancreas as potential local regulators of electrolyte/water transport. Focusing on uroguanylin as a GC-C activating hormone, in the present study we investigated the human pancreas for expression and cellular localization of this peptide hormone compared with those of its receptor, GC-C. In contrast to reports of the presence of uroguanylin primarily in gastrointestinal endocrine cells (Perkins et al. 1997, Magert et al. 1998, Date et al. 1999), our findings show that, in the human pancreas, this peptide is confined exclusively to epithelial cells of the ductal system, where the GC-C receptor is also localized. In view of the fact that CFTR is expressed in exactly these parenchymal elements (Marino et al. 1991), we assume that uroguanylin and GC-C may be involved in the regulation of electrolyte/ water secretion, not only in the intestine but also in the pancreas.

\section{Materials and Methods}

\section{Tissues and tissue preparation}

Tissues of human pancreas $(n=12)$ used in this study were obtained after Whipple operation in patients suffering from pancreatic cancer. Normal tissues were taken outside the tumors and were both macroscopically and histologically normal. Duodenal biopsy specimens from patients who had upper gastrointestinal endoscopy for recurrent abdominal pain were used for RT-PCR analyses. After resection, the tissues were immediately frozen in liquid nitrogen for western blot and RT-PCR analyses or fixed in $4 \%$ aqueous formalin or Bouin's fixative for immunohistochemistry. Gastrointestinal tissues from guinea pig $(n=3)$, serving as reference organs, were treated similarly after flushing of luminal contents with ice-cold saline.

\section{RT-PCR analyses}

For total RNA isolation, $25 \mathrm{mg}$ tissue pieces were homogenized with $600 \mu \mathrm{l}$ homogenization buffer including $20 \mu \mathrm{l} / \mathrm{ml} \mathrm{2}$-mercaptoethanol by $5 \mathrm{~min}$ of shaking at 2000 r.p.m. in a bead mill (Braun, Melsungen, Germany).
RNA was eluted from RNA preparation columns (Qiagen, Hilden, Germany) with RNase-free water and its concentration and purity were analyzed spectrophotometrically $(260 / 280 \mathrm{~nm})$. RNAs were reverse-transcribed with M-MLV Reverse Transcriptase-RNase H Minus (Promega, Madison, WI, USA) according to published procedure (D'Este et al. 2000). For the PCR, primer pairs specific for human uroguanylin (No. U34279) and GC-C (No. M73489) were deduced from the GenBank cDNA sequences and checked for specificity and homology. The primer pair for uroguanylin was: forward $5^{\prime}$-CTC AGG ACC TTC AGC CTG TC; reverse 5'-CCC TCC AAC TCT ATG TCC GA, corresponding to positions 246-265 and 545-526. The primer pair for GC-C was: forward 5'-AGT GAC CTT GGA TGA CTG GG; reverse 5'-AGC TCC AGT GAG GGT GAA GA; corresponding to positions 1145-1164 and 1373-1354. PCR was performed in a thermocycler (MWG-Biotech, Ebersberg, Germany) using $50 \mathrm{ng}$ template cDNA. The amplified PCR products were subsequently separated in a $1.8 \%$ agarose gel. The product length was identified by staining with ethidium bromide and the expected sizes of $\sim 300 \mathrm{bp}$ for uroguanylin and $\sim 229 \mathrm{bp}$ for GC-C were obtained. Glyceraldehyde-3-phosphate-dehydrogenase was used as control. As controls for specificity, the amplified PCRproducts were sequenced by MWG-Biotech.

\section{Peptides, antibodies and antibody generation}

From the human prouroguanylin (Miyazato et al. 1996) sequence, the peptide uroguanylin(69-80) was synthesized as $\mathrm{C}$ terminal amide using a standard Fmoc procedure on a Rainin Symhony multiple peptide synthesizer: after coupling to keyhole limpet hemocyanin using $\mathrm{N}-(3-$ maleinimidobenzoyloxy)-succinimide ester, SPF-rabbits (Charles River, Iffa Credo) were immunized (Eurogentec, Seraing, Belgium) intradermally with $0.2 \mathrm{mg}$ of the peptide conjugate per animal, emulsified in Freund's adjuvant 1:1 ( $\mathrm{vol} / \mathrm{vol})$. The uroguanylin-specific antisera with the highest titers generated were EG(1)-Uro and EG(2)-Uro.

From the human GC-C sequence (de Sauvage et al. 1991), GC-C(31-45) and GC-C(1009-1023) were synthesized and purified according to the procedure described by Cetin et al. (1994, 1995). These peptides were conjugated to keyhole limpet hemocyanin (Sigma, St Louis, MO, USA) by using carbodiimide as coupling agent. Rabbits (New Zealand White, five for each antigen) were immunized subcutaneously with GC-C(31-45) and GCC(1009-1023) conjugates emulsified in complete Freund's adjuvant at 1:1 ( $\mathrm{vol} / \mathrm{vol})$ according to the published procedure (Cetin et al. 1994, 1995, Kulaksiz et al. 2000). The antisera with the highest titers thus generated were $\mathrm{K} 735$, directed against the extracellular domain of GC-C and recognizing GC-C(31-45), and $\mathrm{K} 741$, directed against the intracellular domain and recognizing GCC(1009-1023). 
The peptide epitopes used for the generation of the antibodies displayed no homology to any hitherto reported peptide or protein as checked by the BLAST Email Server.

Monoclonal mouse antibodies against human cytokeratin 18 (DC-10) and 19 (A53-B/A2) were from Santa Cruz Biotechnology (Santa Cruz, CA, USA). For identification of pancreatic endocrine cells, various antisera against chromogranin $\mathrm{A}$ and against the established pancreatic hormones (insulin, glucagon, somatostatin, pancreatic polypeptide) were applied; they have previously been used and characterized (Cetin et al. 1992, 1993).

\section{Extraction of uroguanylin from the human pancreas}

Frozen tissues were powdered and boiled in $1 \mathrm{M}$ acetic acid for $10 \mathrm{~min}$ and homogenized with an Ultra-Turrax homogenizer (Janke \& Kunkel, Staufen, Germany). The homogenates were centrifuged at $20000 \times \mathbf{g}$ for $20 \mathrm{~min}$ at $4{ }^{\circ} \mathrm{C}$ and the supernatants were filtered through a $0.45 \mu \mathrm{m}$ filter. To concentrate the protein content, total tissue extracts were applied to an octadecasilyl (C18) Sep-Pak cartridge (Waters, Milford, MA, USA). The cartridges were washed with $0.01 \mathrm{M} \mathrm{HCl}$ and proteins were eluted with $30 \% \quad(\mathrm{v} / \mathrm{v}) \quad$ 2-propanol/30\% (v/v) methanol/ 0.01 M HCl (Cetin et al. 1994, 1995). The eluted protein fractions were lyophilized and stored at $-80{ }^{\circ} \mathrm{C}$ until required for use.

\section{Western blot analyses}

Proteins from the pancreas were extracted using a Tris$\mathrm{HCl}$ buffer containing $100 \mathrm{mM} \mathrm{NaCl}, 50 \mathrm{mM}$ Tris- $\mathrm{HCl}$, $\mathrm{pH} 7 \cdot 4,10 \%$ glycerol, $1 \%$ Triton X-100, $2 \mu \mathrm{g} / \mathrm{ml} \mathrm{leu-}$ peptin, $2 \mu \mathrm{g} / \mathrm{ml}$ pepstatin, $1 \mathrm{mM}$ phenylmethylsulfonylfluoride. Pancreatic tissue extracts for GC-C and lyophilized protein fractions for uroguanylin were incubated for $7 \mathrm{~min}$ at $94{ }^{\circ} \mathrm{C}$ in sample buffer containing $4 \%$ (wt/vol) SDS (Merck), $50 \mathrm{mM}$ Tris- $\mathrm{HCl}$ (pH 8.45), $1 \mathrm{mM}$ EDTA, $3 \cdot 24 \mathrm{mM}$ dithiothreitol (Roth, Karlsruhe, Germany), $12 \cdot 5 \%$ (wt/vol) glycerol (Merck, Darmstadt, Germany), and 0.0002\% bromphenol blue (Merck). Proteins and peptides were separated in 8\% SDSpolyacrylamide gels for GC-C or in $16.5 \%$ tricineSDS-polyacrylamide gels for uroguanylin as previously described (Cetin et al. 1994, 1995, Kulaksiz et al. 2000). After electrophoresis, proteins were electroblotted onto polyvinylidene fluoride-based membranes (Pall, Dreieich, Germany). Unspecific bindings of the antibodies were blocked by incubation of the membranes in 3\% bovine serum albumine in Tris-buffered saline (TBST) containing $10 \mathrm{mM}$ Tris- $\mathrm{HCl}(\mathrm{pH} 8 \cdot 0), 150 \mathrm{mM} \mathrm{NaCl}$, and $0.05 \%$ Tween 20 . The membranes were incubated overnight at $4{ }^{\circ} \mathrm{C}$ with antisera EG(1)-Uro, EG(2)-Uro, K735 and K741 (diluted 1:1000 in TBST). To visualize immunoreactive proteins, blot strips were incubated with alkaline phosphatase-conjugated goat anti-rabbit IgG (diluted 1:20 000, Sigma) using nitro blue tetrazolium and 5-bromo-4-chloro-3-indolyl phophate as chromogens (Sigma). The immunoreaction in western blots was specifically blocked after preincubation of the antibodies with the corresponding peptide immunogens. Any crossreactions with the second goat anti-rabbit antibody were excluded by appropriate controls.

\section{Immunohistochemistry and immunofluorescence}

Pancreatic tissues were fixed for $20 \mathrm{~h}$ in $4 \%$ aqueous formalin or in Bouin's fixative, dehydrated and embedded in paraffin. Paraffin sections $(4 \mu \mathrm{m})$ were immunostained using the modified avidin-biotin-peroxidase complex technique (Cetin et al. 1992, 1993). The sections were incubated overnight at $4{ }^{\circ} \mathrm{C}$ with the antisera EG(1)-Uro, EG(2)-Uro (both diluted 1:1000 in PBS), K735 and K741 (1:500), monoclonal anti-human cytokeratin 18 and 19 $(1: 1500)$ and the respective pancreatic endocrine cell antibodies, followed by incubation with biotinylated anti-rabbit or anti-mouse $\operatorname{IgG}$ (Dako, Hamburg, Germany) for $30 \mathrm{~min}$ in a dilution of 1:200. Doublelabeling experiments were performed by immunofluorescence microscopy using the same antisera. After incubation with the respective antisera, staining was performed by incubation with Cy2- and Cy3-labeled antibodies against mouse and rabbit IgG (1:200) (Dianova, Hamburg, Germany). The immunolabelings were investigated in a Zeiss Axioplan microscope equipped with appropriate filters.

Specificity controls of immunostaining Methoddependent non-specificities were excluded by running controls as previously described (Cetin et al. 1992, 1993 1994, 1995, Kulaksiz et al. 2000). Antibody specificities were tested by preadsorption of the antisera with the corresponding peptide immunogens and with heterologous antigens $(6 \cdot 25-50 \mu \mathrm{g}$ antigen per $\mathrm{ml}$ of antiserum in working dilution). All controls confirmed the specificity of immunostainings.

\section{Results}

\section{Expression of uroguanylin and GC-C in the human pancreas}

RT-PCR analyses showed that uroguanylin and GC-C are expressed in the human pancreas. The specific uroguanylin and GC-C primers constructed yielded amplification products of correct molecular sizes in the human pancreas and duodenum (positive control) (Fig. 1). The amplified PCR products were sequenced and thus clearly revealed that the sequences for pancreatic uroguanylin and GC-C exhibit a complete homology to their intestinal forms.

The presence of uroguanylin and GC-C in the human pancreas at the translational level was investigated by western blotting using antibodies specific for uroguanylin 


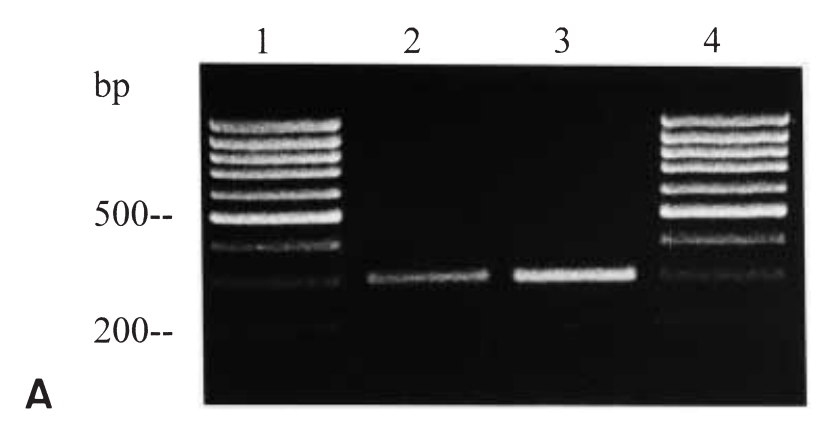

\section{A}

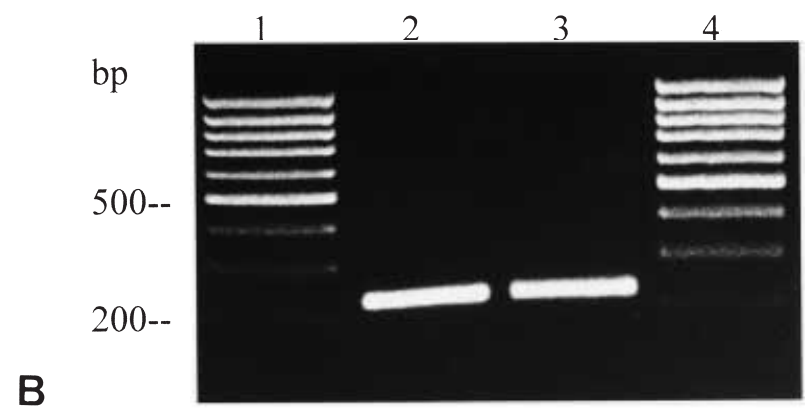

Figure 1 RT-PCR analyses of gene expression of uroguanylin (A) and GC-C (B) in the human pancreas (lanes 2) and duodenum (lanes 3, positive control), with amplification products of correct molecular sizes. 100 bp DNA ladder is indicated (lanes 1 and 4).

and GC-C. Thus uroguanylin of $\sim 12.5 \mathrm{kDa}$ molecular mass was identified in extracts of the human pancreas as well as of the intestine (positive control) (Fig. 2). Likewise, GC-C with a molecular mass of $\sim 130 \mathrm{kDa}$ was detected in pancreatic and intestinal extracts (Fig. 2).
Cellular localization of uroguanylin and guanylate cyclase $C$ in the human pancreas

Using immunohistochemistry or immunofluorescence, the specific uroguanylin antisera EG(1)-Uro and EG(2)-Uro coincidently immunostained distinctive cells distributed in the exocrine pancreas. By their typical location within the acini, these cells were identified as centroacinar cells (Fig. 3) which, as epithelial constituents of the ductal system, displayed immunoreactivity for the epithelial markers cytokeratin 18 and cytokeratin 19 (Fig. 4). In addition, uroguanylin immunoreactivity was present in epithelial cells lining the intercalated, intralobular and interlobular ducts; in double-labeling experiments, these cells also revealed immunoreactivity for cytokeratin 18 and 19 (Fig. 4). Thus uroguanylin was distributed in the pancreatic ductal system extending from centroacinar cells to the interlobular ducts. Despite this clear parenchymal distribution of uroguanylin, it was evident that the intensity of immunostaining varied considerably among the various segments of the ductal network. The immunoreactivity for uroguanylin was mostly strong in the proximal part of the ductal system (centroacinar cells, intercalated and intralobular ducts), but it proved to decrease continuously towards the distal parts of the ductal network (small- and large-sized interlobular ducts). This type of heterogeneity was observed between the ducts of the same pancreatic lobe or even between the epithelial cells of the same ducts: among the strongly uroguanylinimmunoreactive cells, a variable number of ductal cells were detected that were faintly immunoreactive or even totally unreactive for uroguanylin (Fig. 3). In addition, intercellular differences were evident with regard to distribution of uroguanylin immunoreactivity at the cellular level; uroguanylin immunoreactivity was present in the entire cytoplasm of the epithelial duct cells exhibiting a granular pattern of immunostaining. In many ducts, this

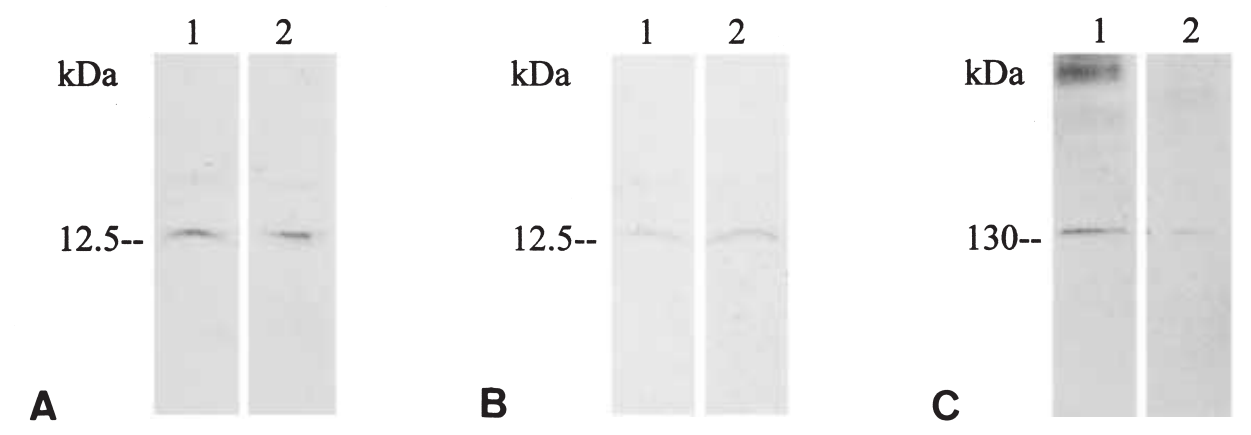

Figure 2 Western blot analyses of uroguanylin (A and B) and GC-C (C) in extracts of the human pancreas. Both uroguanylin antibodies (A, EG(1)-Uro; B, EG(2)-Uro) identify the immunoreactive uroguanylin of $\sim 12.5 \mathrm{kDa}$ molecular mass in the guinea pig intestine (lanes 1 , positive control) and human pancreas (lanes 2). The immunoreactive GC-C of $\sim 130 \mathrm{kDa}$ molecular mass is detected by the domain-specific antibody K735 in the guinea pig duodenum (lane 1, positive control) and human pancreas (lane 2). 


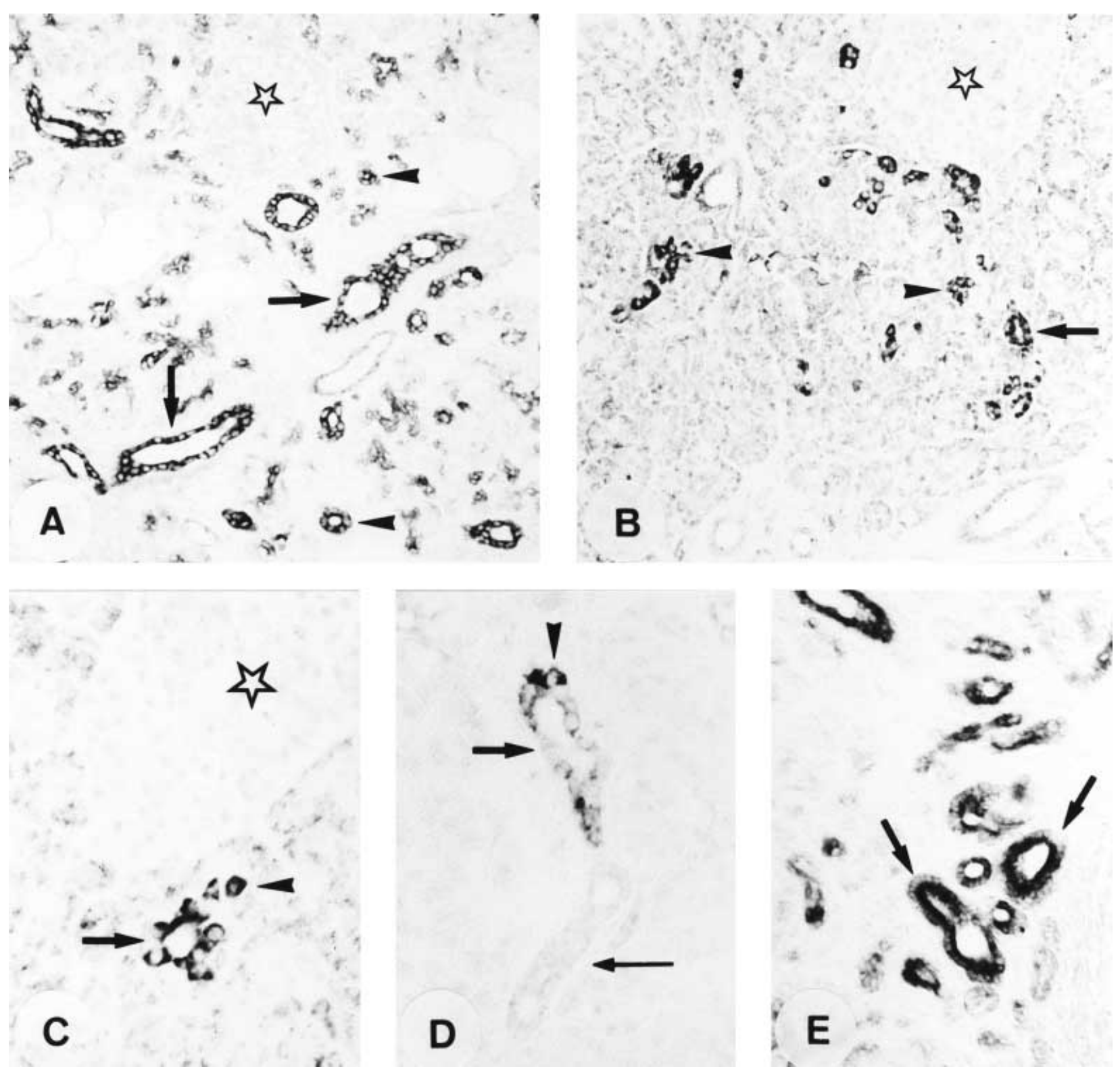

Figure 3 Cellular localization of uroguanylin in the human pancreas $(n=7)$. The uroguanylin-specific antibody EG(1)-Uro localizes immunoreactive uroguanylin not only in the intralobular ducts (A, arrows) but also in the intercalated duct cells (A, arrowheads; B, arrow) and in the centroacinar cells (B, arrowheads). The antibody EG(2)-Uro coincidently localizes uroguanylin in the same epithelial cells of the intralobular and intercalated ducts $(\mathrm{C}$, arrow) and in the centroacinar cells $(\mathrm{C}$, arrowhead). Note that the islets of Langerhans are completely unreactive for uroguanylin (A-C, asterisks). Uroguanylin immunoreactivities of varying densities are observed between the ducts of the same lobule as demonstrated in D (arrows); intercellular differences exist even in the same ducts showing strongly (D, arrowhead) and faintly immunoreactive or unreactive (D, short arrow) epithelial cells. In some ducts uroguanylin immunoreactivity is concentrated at the apical pole of the epithelial cells (E, arrows). Original magnifications: A and E, $\times 180 ; B, \times 220 ; C$ and D, $\times 360$.

immunoreactivity was typically concentrated adluminally at the apical pole of the respective epithelial cells (Fig. 3).

Of note, acinar gland cells, islets of Langerhans or the established extrainsular endocrine cells (A-, B-, D- and PP-cells), which were identified by the appropriate antisera completely lacked any immunoreactivity for uroguanylin (Fig. 3).
Consistent with the cellular distribution of uroguanylin, both GC-C antisera K735 and K741, specific for the extra- and intracellular domain, coincidently localized this receptor exclusively to the exocrine parenchyma confined to centroacinar, intercalated, intralobular and interlobular duct epithelial cells. In all these segments of the ductal system, the receptor GC-C was found exclusively at the 

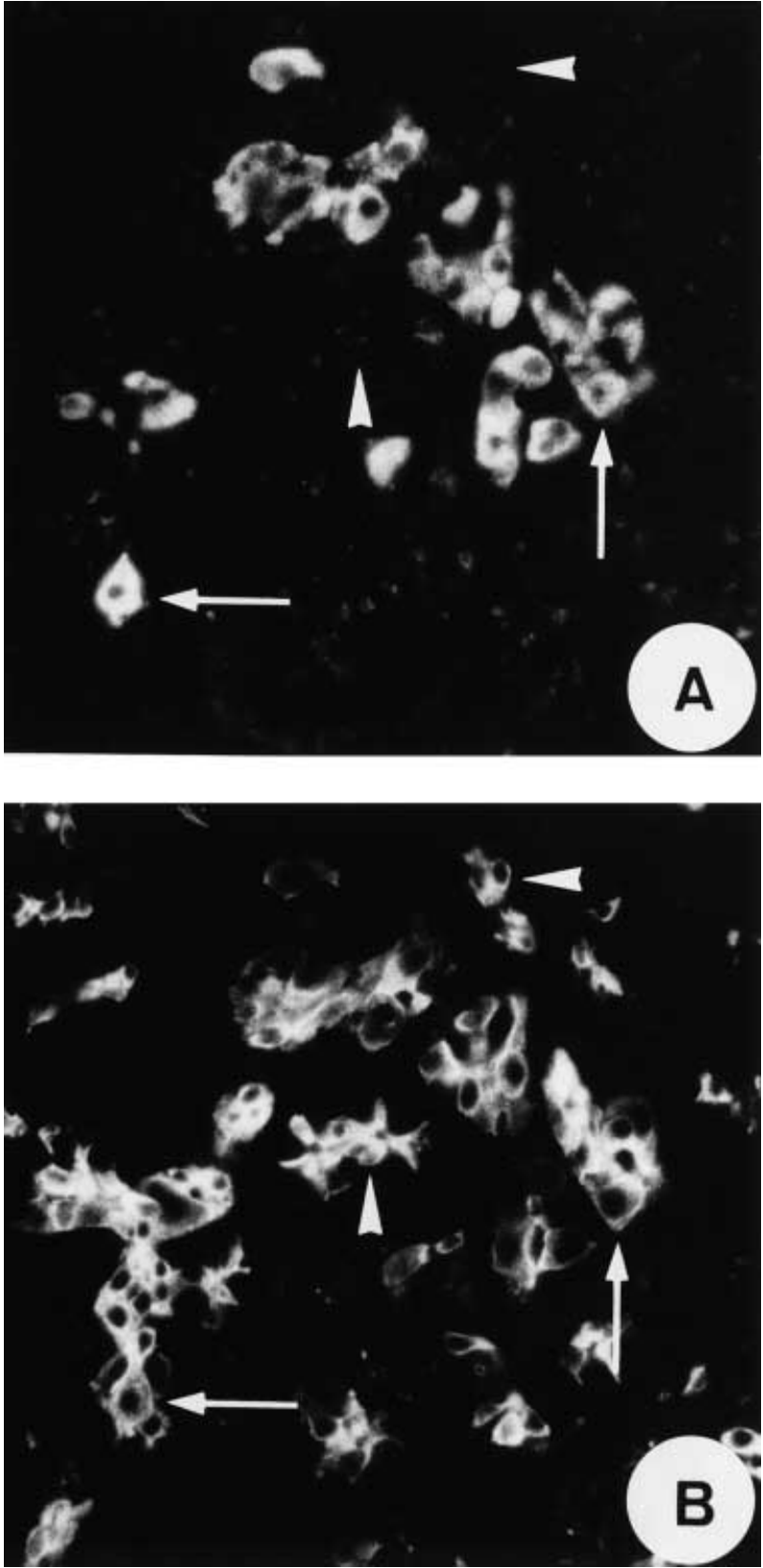

Figure 4 Cellular localization of uroguanylin with the immunofluorescence technique $(n=4)$. Correlative immunofluorescence double labeling with antibodies EG(1)-Uro (A) and CK18 (B) shows that uroguanylin is localized in cytokeratin 18-positive cells (arrows); however, not all CK18 positive cells are immunoreactive for uroguanylin (arrowheads). Original magnifications: $\mathrm{A}$ and $\mathrm{B}, \times 60$.

apical membrane of the epithelial cells (Fig. 5). In no case was immunostaining for $\mathrm{GC}-\mathrm{C}$ detected at the basolateral membrane of either acinar gland cells or epithelial cells of small- and large-sized ducts. Likewise, the islets of
Langerhans or the various endocrine cell types scattered in the exocrine parenchyma were completely unreactive for GC-C.

\section{Discussion}

The present RT-PCR analyses with specific primers showed that uroguanylin is expressed in the human pancreas, as it is in the intestine, which was used as reference organ. The existence of uroguanylin at the translational level was verified by western blotting experiments. Uroguanylin-specific antibodies clearly identified the immunoreactive peptide in the range of $\sim 12.5 \mathrm{kDa}$ molecular mass in pancreatic tissue extracts; the size of this pancreatic peptide comigrating with the immunoreactive band in intestinal homogenates (positive control) (Cetin et al. 1994) corresponds to the molecular mass of uroguanylin deduced from the respective cDNA sequence (Miyazato et al. 1996). In all extracts including positive controls, however, both antibodies also yielded a faintly stained band that may have been due to a related protein of higher molecular mass $(\sim 17 \mathrm{kDa})$, the existence of which has been speculated on in previous studies (Cetin et al. 1994, 1995, D'Este et al. 2000).

On the basis of present data at the transcriptional and translational levels, we conclude that the human pancreas is a source of uroguanylin. This is further corroborated by the additional existence of the uroguanylin receptor, GC-C, in the same organ. RT-PCR analyses with specific primers identified expression of $\mathrm{GC}-\mathrm{C}$ in the human pancreas as well as in the duodenum. Western blots with antisera specific for the extracellular and intracellular domains of GC-C consistently confirmed the presence of GC-C as a $\sim 130 \mathrm{kDa}$-protein in the human pancreas and in the reference organ. This molecular mass of immunoreactive $\mathrm{GC}-\mathrm{C}$ obtained corresponds to that deduced from the respective cDNA sequence (de Sauvage et al. 1991) and is completely in line with previous data from the intestine (Schewing et al. 1996). The simultaneous existence of uroguanylin and $\mathrm{GC}-\mathrm{C}$ in the human pancreas implies that uroguanylin is an intrinsic pancreatic peptide acting locally within this organ.

To analyze the cellular source of uroguanylin and the respective target cells and membrane domains, immunohistochemical studies at the cellular level were performed. These investigations revealed that uroguanylin is exclusively confined to the exocrine pancreas where it was localized to the centroacinar cells and to epithelial cells of the intercalated, intralobular and interlobular ducts identified by the antibodies against cytokeratin 18 and 19 .

Remarkably, in all pancreatic tissues investigated, the islets of Langerhans and the various extrainsular endocrine cell types completely lacked immunoreactivity for uroguanylin. However, in a recent study uroguanylin immunoreactivity was described in islets B-cells of the rat and 


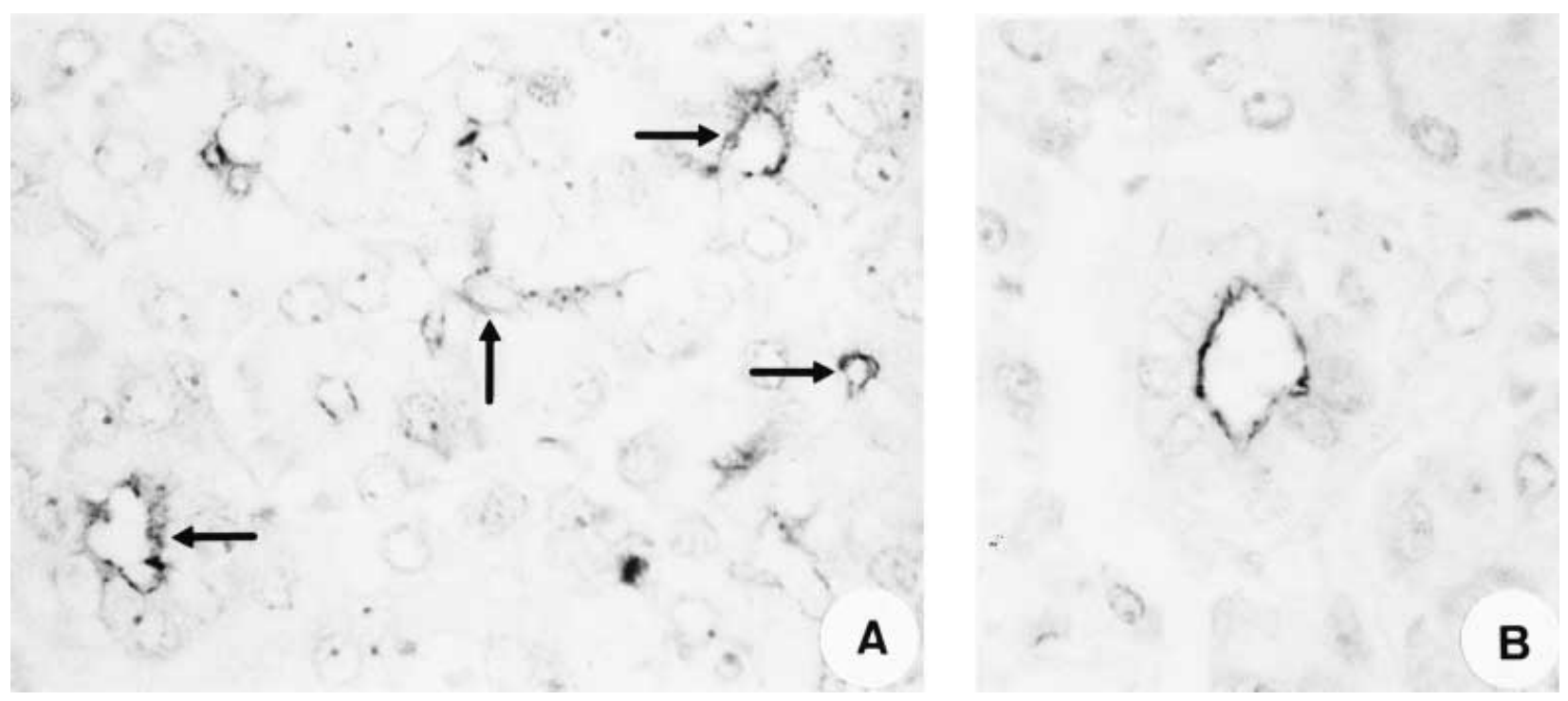

Figure 5 Cellular localization of GC-C in the human pancreas $(n=6)$. Paraffin sections showing that GC-C, localized by the domain-specific antibody K735, is confined to the apical membrane of intercalated (A, arrows) and intralobular (B) duct epithelial cells. Original magnifications: $\mathrm{A}$ and $\mathrm{B}, \times 360$.

interpreted as merely a vestige of the evolutionary process (Nakazato et al. 1998). We assume that this discrepancy may be due to species-specificities of uroguanylin expression between rat and man, or to differences in the specificity and binding characteristics of the uroguanylin antibodies used. Our present findings with two different uroguanylin-specific antibodies show that, in the human pancreas, the epithelial cells of the ductal system are the main source of uroguanylin which, intriguingly, fits the cellular localization of the receptor and also that of CFTR, as detailed below.

Notably, within the ductal system, the various segments proved to be heterogeneous with respect to the intensity of uroguanylin immunoreactivity: although the immunoreactivity was present from the centroacinar to the interlobular duct cells, it was rather strongly expressed in the intralobular duct system and became continuously weaker towards the interlobular ducts. Heterogeneity in the density of the immunoreactivity was also observed between the cells even of the same ducts, which may reflect intercellular differences in expression, storage and secretion of uroguanylin. In this respect, immunohistochemical studies at the cellular level revealed a granular pattern of uroguanylin immunoreactivity within the ductal cells, suggesting localization of the peptide in small secretory vesicles; indeed, these cells have been demonstrated to exhibit characteristics typical of secretory cells and to contain small secretory vesicles characterized by electron microscopy (Case \& Argent 1993).

The comparative analysis of tissue distribution and cellular localization of $\mathrm{GC}-\mathrm{C}$ revealed that this uroguanylin-receptor is not present in the endocrine pancreas, but was localized exclusively to the ductal system which fully corresponds to the GC-C activity detected in the exocrine ductal system, but particularly not in islets of Langerhans (Rambotti et al. 2000).

Within the ductal branching, GC-C immunoreactivity was attributed to centroacinar cells, epithelial cells of the intercalated, intralobular and interlobular ducts. In these segments at the cellular level, GC-C was exclusively detected adluminally localized to the apical membrane of the respective ductal cells. This particular apical localization of GC-C implies a luminal stimulation of the receptor through the pancreatic juice. As uroguanylin is localized exclusively to secretory ductal cells frequently concentrated to their apical portion, we assume that the centroacinar and the proximal duct cells release uroguanylin luminally into the pancreatic juice to stimulate apical GC-C of the same or post-positioned duct epithelial cells, comparable to the luminal activation of GC-C by guanylin or uroguanylin in the intestine (Schulz et al. 1990, Garbers 1992, Seidler et al. 1997). In any case, the cellular distribution of GC-C in the human pancreas completely matches the cell- and membrane-domain-specific localization of CFTR, a $\mathrm{Cl}^{-}$channel and regulator protein, crucially involved in electrolyte secretion in the pancreas (Case \& Argent 1993, Quinton 1999). This particular cellular organization of $\mathrm{GC}-\mathrm{C}$ is certainly of importance, because recent findings in the intestine clearly demonstrated that stimulation of GC-C by guanylin or uroguanylin couples to activation of CFTR (Cuthbert et al. 1994, Seidler et al. 1997) in terms of electrolyte/water secretion (Hamra et al. 1993, Cuthbert et al. 1994, Seidler et al. 1997, Joo et al. 1998). 
In conclusion, the present data show that uroguanylin is not only present in gastrointestinal endocrine cells (Perkins et al. 1997, Magert et al. 1998, Date et al. 1999) but may also be expressed in duct epithelial cells of the human pancreas. On the basis of the fact that uroguanylin and GC-C specifically couple to activation of CFTR and thus regulation of electrolyte/water secretion as demonstrated in the intestinal epithelium (Cuthbert et al. 1994, Seidler et al. 1997, Joo et al. 1998), the expression of uroguanylin and of its receptor $\mathrm{GC}-\mathrm{C}$ in the human pancreas argues for regulation of pancreatic electrolyte secretion via CFTR. In this respect, the mutual cell- and membrane-specific localizations of uroguanylin and GC-C predictably reveal an intriguing paracrine/luminocrine signaling pathway in situ.

\section{Acknowledgements}

We thank Mrs C Merte-Grebe and T Seitz for their expert technical assistance. This study was supported by grants of the Deutsche Forschungsgemeinschaft, Stiftung P E Kempkes, Marburg, Research Pool of the Philipps University Marburg.

\section{References}

Case RM \& Argent BE 1993 Pancreatic duct cell secretion. Control and mechanisms of transport. In The Pancreas, pp 301-350. Eds VLW Go \& EP DiMagno. New York: Raven Press.

Cetin Y, Bargsten G \& Grube D 1992 Mutual relationships between chromogranins $\mathrm{A}$ and $\mathrm{B}$ and gastrin in individual gastrin cells. PNAS 89 2912-2916.

Cetin Y, Aunis D, Bader MF, Galindo E, Jörns A, Bargsten G \& Grube D 1993 Chromostatin, a chromogranin A-derived bioactive peptide, is present in human pancreatic insulin $(\beta)$ cells. PNAS 90 2360-2364.

Cetin Y, Kuhn M, Kulaksiz H, Adermann K, Bargsten G, Grube D \& Forssmann WG 1994 Enterochromaffin cells of the digestive system: cellular source of guanylin, a guanylate cyclase-activating peptide. PNAS 91 2935-2939.

Cetin Y, Kulaksiz H, Redecker P, Bargsten G, Adermann K, Grube D \& Forssmann WG 1995 Bronchiolar nonciliated secretory (Clara) cells: source of guanylin in the mammalian lung. PNAS $\mathbf{9 2}$ 5925-5929.

Currie MG, Fok KF, Kato J, Moore RJ, Hamra FK, Duffin KL \& Smith CE 1992 Guanylin: an endogenous activator of intestinal guanylate cyclase. PNAS 89 947-951.

Cuthbert AW, Hickman ME, MacVinish LJ, Evans MJ, Colledge WH, Ratcliff R, Seale PW \& Humphrey PPA 1994 Chloride secretion in response to guanylin in colonic epithelia from normal and transgenic cystic fibrosis mice. British Journal of Pharmacology $11231-36$.

Date Y, Nakazato M, Yamaguchi H, Kangawa K, Kinoshita Y, Chiba T, Ueta Y, Yamashita H \& Matsukura S 1999 Enterochromaffinlike cells, a cellular source of uroguanylin in rat stomach. Endocrinology 140 2398-2404.

D’Este L, Kulaksiz H, Rausch U, Vaccaro R, Wenger T, Tokunaga Y, Renda TG \& Cetin Y 2000 Expression of guanylin in 'pars tuberalis-specific cells' and gonadotrophs of rat adenohypophysis. PNAS 97 1131-1136.
Forte LR, Eber SL, Fan X, London RM, Wang Y, Rowland LM, Chin DT, Freeman RH \& Krause WJ 1999 Lymphoguanylin: cloning and characterization of a unique member of the guanylin peptide family. Endocrinology 140 1800-1806.

Forte LR, London RM, Freeman RH \& Krause WJ 2000 Guanylin peptides: renal actions mediated by cyclic GMP. American Journal of Physiology 278 F180-F191.

Garbers DL 1992 Guanylyl cyclase receptors and their endocrine, paracrine, and autocrine ligands. Cell 71 1-4.

Hamra FK, Forte LR, Eber SL, Pidhorodeckyj NV, Krause WJ, Freeman RH, Chin DT, Tompkins JA, Fok KF, Smith CE, Duffin KL, Siegel NR \& Currie MG 1993 Uroguanylin: structure and activity of a second endogenous peptide that stimulates intestinal guanylate cyclase. PNAS 90 10464-10468.

Joo NS, London RM, Kim HD, Forte LR \& Clarke LL 1998 Regulation of intestinal $\mathrm{Cl}^{-}$and $\mathrm{HCO}_{3}{ }^{-}$secretion by uroguanylin. American Journal of Physiology 274 G633-G644.

Krause WJ, London RM, Freeman RH \& Forte LR 1997 The guanylin and uroguanylin peptide hormones and their receptors. Acta Anatomica 160 213-231.

Kulaksiz H, Arnold R, Göke B, Maronde E, Meyer M, Fahrenholz F, Forssmann WG \& Eissele R 2000 Expression and cell-specific localization of the cholecystokinin $\mathrm{B} /$ gastrin receptor in the human stomach. Cell and Tissue Research 299 289-298.

Lee MG, Choi LY, Luo X, Strickland E, Thomas PJ \& Muallem S 1999 Cystic fibrosis transmembrane conductance regulator regulates luminal $\mathrm{Cl}^{-} / \mathrm{HCO}_{3}{ }^{-}$exchange in mouse submandibular and pancreatic ducts. Journal of Biological Chemistry 274 14670-14677.

Lewis LG, Witte DP, Laney DW, Currie MG \& Cohen MB 1993 Guanylin mRNA is expressed in villous enterocytes of the rat small intestine and superficial epithelia of rat colon. Biochemical and Biophysical Research Communications 196 553-560.

Lohmann SM, Vaandrager AB, Smolenski A, Walter U \& de Jonge HR 1997 Distinct and specific functions of cGMP-dependent protein kinases. Trends in Biochemical Sciences 22 307-312.

Magert HJ, Reinecke M, David I, Raab HR, Adermann K, Zucht HD, Hill O, Hess R \& Forssmann WG 1998 Uroguanylin: gene structure, expression, processing as a peptide hormone, and co-storage with somatostatin in gastrointestinal D-cells. Regulatory Peptides 73 165-176.

Marino CR, Matovcik LM, Gorelick FS \& Cohn JA 1991 Localization of the cystic fibrosis transmembrane conductance regulator in pancreas. Journal of Clinical Investigations 88 712-716.

Miyazato M, Nakazato M, Yamaguchi H, Date Y, Kojima M, Kangawa K, Matsuo H \& Matsukura S 1996 Cloning and characterization of a cDNA encoding a precursor for human uroguanylin. Biochemical and Biophysical Research Communications 219 644-648.

Nakazato M, Yamaguchi H, Date Y, Miyazato M, Kangawa K, Goy MF, Chino N \& Matsukura S 1998 Tissue distribution, cellular source, and structural analysis of rat immunoreactive uroguanylin. Endocrinology 139 5247-5254.

Perkins A, Goy MF \& Li Z 1997 Uroguanylin is expressed by enterochromaffin cells in the rat gastrointestinal tract. Gastroenterology 113 1007-1014.

Quinton PM 1999 Physiological basis of cystic fibrosis: a historical perspective. Physiological Reviews 79 3-22.

Rambotti MG, Giambanco I \& Spreca A 2000 Ultracytochemical detection of guanylate cyclase $\mathrm{C}$ activity in alimentary tract and associated glands of the rat. Influence of $\mathrm{pH}, \mathrm{ATP}$ and the ions $\mathrm{Mg}^{2+}$ and $\mathrm{Mn}^{2+}$. Histochemical Journal 32 231-238.

de Sauvage FJ, Camerato TR \& Goeddel DV 1991 Primary structure and functional expression of the human receptor for Escherichia coli heat-stable enterotoxin. Journal of Biological Chemistry 266 17912-17918. 
de Sauvage FJ, Keshav S, Kuang WJ, Gillett N, Henzel W \& Goeddel DV 1992 Precursor structure, expression, and tissue distribution of human guanylin. PNAS 89 9089-9093.

Schewing LA, Russell WE \& Chong KM 1996 Structure, glycosylation, and localization of rat intestinal guanylyl cyclase C: modulation by fasting. American Journal Physiology 271 G959-G968.

Schulz S, Green CK, Yuen PST \& Garbers DL 1990 Guanylyl cyclase is a heat-stable enterotoxin receptor. Cell 63 941-948.

Seidler U, Blumenstein I, Kretz A, Viellard-Baron D, Rossmann H, Colledge WH, Evans M, Ratcliff R \& Gregor M 1997 A functional CFTR protein is required for mouse intestinal cAMP-, cGMP- and $\mathrm{Ca}^{2+}$-dependent $\mathrm{HCO}_{3}{ }^{-}$secretion. Journal of Physiology 505 411-423.
Trezise AEO \& Buchwald M 1991 In vivo cell-specific expression of the cystic fibrosis transmembrane conductance regulator. Nature $\mathbf{3 5 3}$ 434-437.

Vaandrager AB, Smolenski A, Tilly BC, Houtsmuller AB, Ehlert EME, Bot AGM, Edixhoven M, Boomaars WEM, Lohmann SM \& de Jonge HR 1998 Membrane targeting of cGMP-dependent protein kinase is required for cystic fibrosis transmembrane conductance regulator $\mathrm{Cl}^{-}$channel activation. PNAS 95 $1466-1471$.

Received 14 December 2000 Accepted 22 March 2001 